\title{
Rejeitos de mineração e (des)controles ambientais em uma área costeira brasileira ${ }^{1}$
}

\author{
Mine tailings and enviromental (dis)controls in \\ a Brazilian coastal area
}

\section{Eliana Creado* ${ }^{1}$}

Palavras-chave:

Desastre;

Toxicidade;

Relações entre humanos

e não-humanos.

Keywords:

Disaster;

Toxicity;

Relations between

humans and non-

humans.

\begin{abstract}
Resumo: $O$ ensaio foi escrito a partir de experiências de campo vivenciadas desde 2011, e realizadas em diferentes formatos e colaborações, em pesquisas que, grosso modo, versaram sobre relações socioambientais em Regência Augusta, ES. Apresenta compilação de imagens do período entre 2015 e 2020, focando enredamentos trazidos a partir da chegada de rejeitos da mineração de ferro carregados ao longo de cursos d'água, desde a barragem da Samarco S.A., rompida, à montante no rio Doce, em 2015. Os enredamentos fizeram aflorar outros anteriores, ligados à exploração de óleo e gás, feita nas proximidades. Buscamos, em diálogo com outros trabalhos, trazer um pouco da multiplicidade das águas, com diferentes dimensões materiaissimbólicas, e refletir sobre as reincidências de desastres. A equação poluidor-pagador e iniciativas de regeneração fazem-se presentes, em meio a perdas que se acumulam.
\end{abstract}

Abstract: The essay was written from field experiences lived since 2011, wich were carried out in different formats and collaborations and in different researches that, roughly speaking, dealt with socio-environmental relations in Regência Augusta, ES. It brings a small compilation of images from the period between 2015 and 2020, focusing on entanglements brought from the arrival of iron mining tailings carried along water courses, from the collapsed Samarco S.A. dam, situated in the upstreamer area of Doce river, in 2015. Such entanglements

\footnotetext{
1 A primeira versão deste ensaio foi elaborada para o site Toxic News https://toxicnews.org/, em 28 de fevereiro de 2020. Agradecemos a Patrício Flores pelo contato e pela mediação. O material também embasou apresentação oral na Mesa Redonda 039, Vínculos Terranos: histórias de destruição e reconstrução em Brasil e Chile, realizada durante a 32a Reunião Brasileira de Antropologia.

*1 Doutora em Ciências Sociais, UNICAMP. Docente em Antropologia, DCSo, Universidade Federal do Espírito Santo (UFES). Vincula-se ao grupo Ambiências-UFES: dgp.cnpq.br/dgp/espelhogrupo/0002469966514576.
} 
brought out other previous entanglements, linked to the exploration of oil and gas, this one carried out in the vicinity. We seek, in dialogue with other works, to bring the multiplicity of water, with its different material-symbolic dimensions, as well as to reflect on the recurrence of disasters. Polluter pays principle and regeneration initiatives are both presente, in attempts to live amid losses.

$\mathrm{Q}$ uando começamos a estudar as possibilidades de desastres sociotecnológicos (ZHOURI et al., 2017) em Regência Augusta, Espírito Santo (ES), uma vila de pescadores onde o rio Doce encontra o Oceano Atlântico, pensávamos em algo relacionado à infraestrutura de exploração e distribuição de gás ou óleo. Era a primeira metade do ano de 2015, e participávamos de um programa de extensão, desenvolvido pelo Grupo de Estudos e Pesquisa em Populações Pesqueiras e Desenvolvimento (GEPPEDES), da Universidade Federal do Espírito Santo (UFES), coordenado pela profa. Dra. Aline Trigueiro. ${ }^{2}$

O projeto foi escrito antes de outro desastre que acometeu a região a partir do final de 2015; seus objetivos e atuações precisaram ser adequados a esse trágico acontecimento. Falaremos sobre ele adiante.

Na praia da vila, um pouco antes de chegarmos à Regência Augusta, existem cinco grandes tanques de armazenamento de óleo, situados nas proximidades de uma área protegida devotada à conservação de ninhos de tartarugas marinhas, a Reserva Biológica de Comboios (REBio Comboios), localizada na praia de mesmo nome (TORRES et al., 2017). Se nos deslocarmos rumo ao norte, seguindo o rio Doce, a presença dessa estrutura torna-se bem grotesca, pois os próprios dutos afloram para cima da terra, sobretudo nas proximidades de Areal e Entre Rios.

\footnotetext{
2 Todas as fotografias foram tiradas pela autora, em diferentes ocasiões, atuações de extensão e pesquisa e em diversas colaborações e companhias. São imagens com objetivos documentais, sem pretensões estéticas. A autora atua na região desde 2011 e continua atuando. Entre 2015 e 2018, fê-lo vinculada ao programa integrado de pesquisa e extensão realizado junto ao GEPPEDES-UFES: "Áreas Protegidas e Grandes Projetos de Desenvolvimento no Horizonte de Vivências das Comunidades Locais: os impactos socioambientais e os seus desdobramentos". À época, houve o financiamento do Ministério da Educação (MEC) pelo edital Proext-2016 (conferir CREADO et al., 2018; TRIGUEIRO et al., 2018).
}

Caderno Eletrônico de Ciências Sociais, Vitória, v. 8, n. 2, pp. 84-106, 2020. 


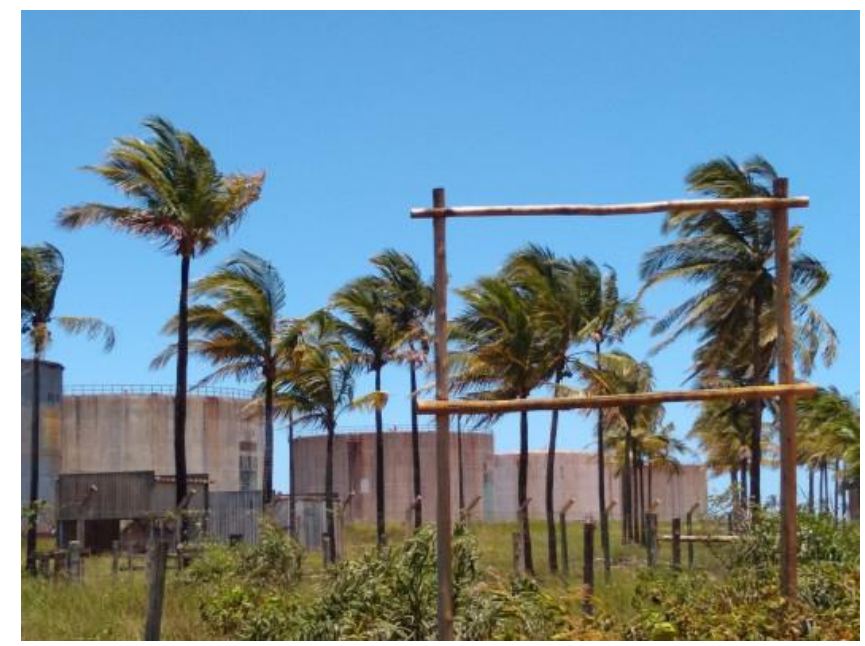

Figura 1: Tanques de armazenamento de óleo, como um enclave na REBio de Comboios, vizinhanças da vila de Regência Augusta. Fevereiro, 2020.

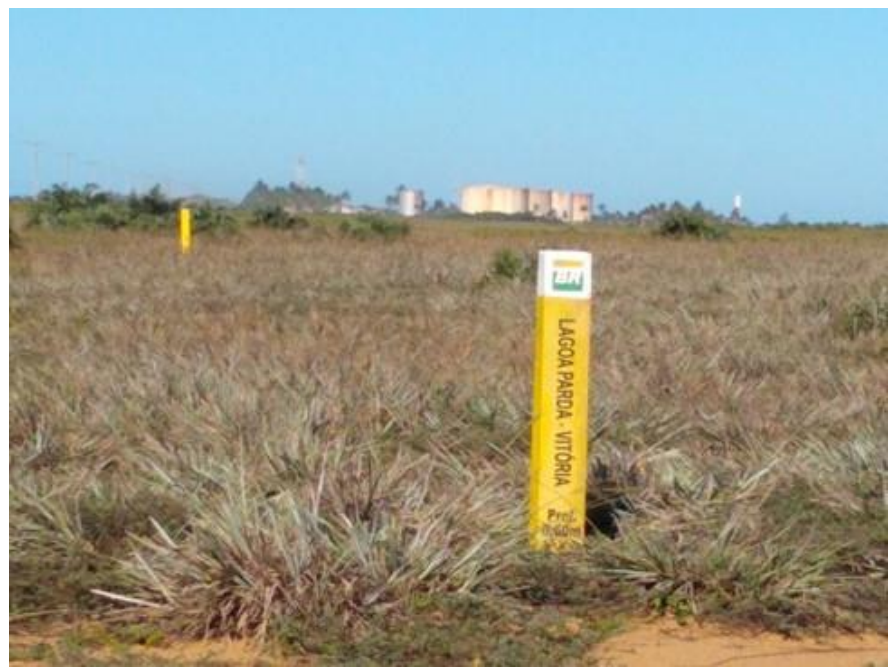

Figura 2: Marcações do caminho do gasoduto e tanques de armazenamento de óleo, através da vegetação de restinga, REBio de Comboios. Fevereiro, 2020.

As duas comunidades também convivem com bombas de sucção de óleo e gás, os chamados "cavalinhos". ${ }^{3}$ Com afirma Rafael Pagatini (2017, s.p.):

Neste contexto o termo "cavalo" tanto faz referência ao animal quanto a unidade de medida de potência utilizada para expressar força. As máquinas são instaladas com a promessa de pagamento de royalty, mas poluem o solo, o lençol freático e inviabilizam a produção de alimentos no local, tornam-se símbolos de um racionalismo empobrecido e obsoleto.

\footnotetext{
${ }^{3}$ Colocamos as expressões locais entre aspas.
} 
Especialmente em Areal, os dutos percorrem o território bem próximos às casas, e crianças brincam ao lado deles. Em uma das idas a campo, ouvimos sobre um acidente ocorrido entre o final da década de 1970 e o começo da década de 1980, quando, durante uma instalação dessa infraestrutura, um vazamento de gás gerou uma "língua de fogo" que durou 18 dias (TRIGUEIRO et al., 2018, pp. 23-24). Hoje em dia, as bombas de sucção e os dutos estão acompanhados de sinalização de perigo que revelam e, ao mesmo tempo, normalizam os riscos à vida, no caso humanas (cf. PERROW, 1999 apud TADDEI, 2020, p. 55).

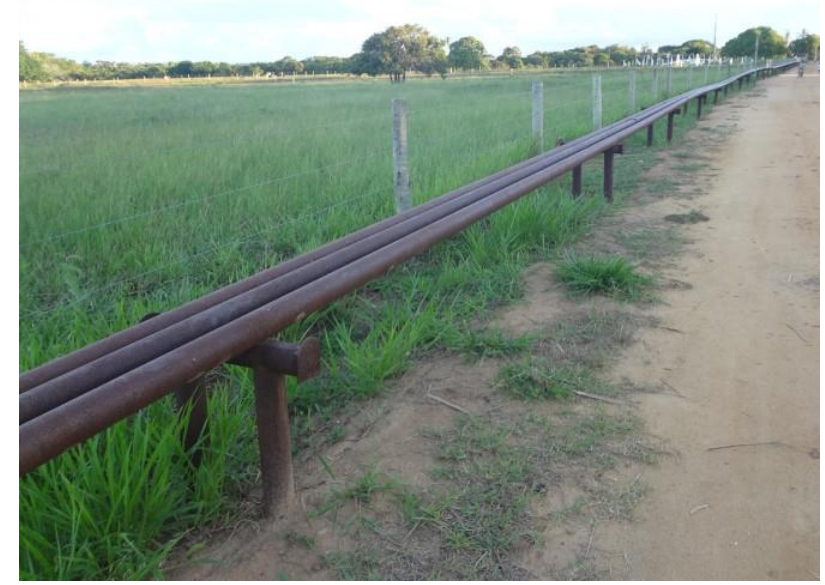

Figura 3: Duto em Areal. Fevereiro, $2017 .{ }^{4}$

\footnotetext{
${ }^{4}$ Foto publicada também em Creado e colaboradores (2018, p. 28)
} 


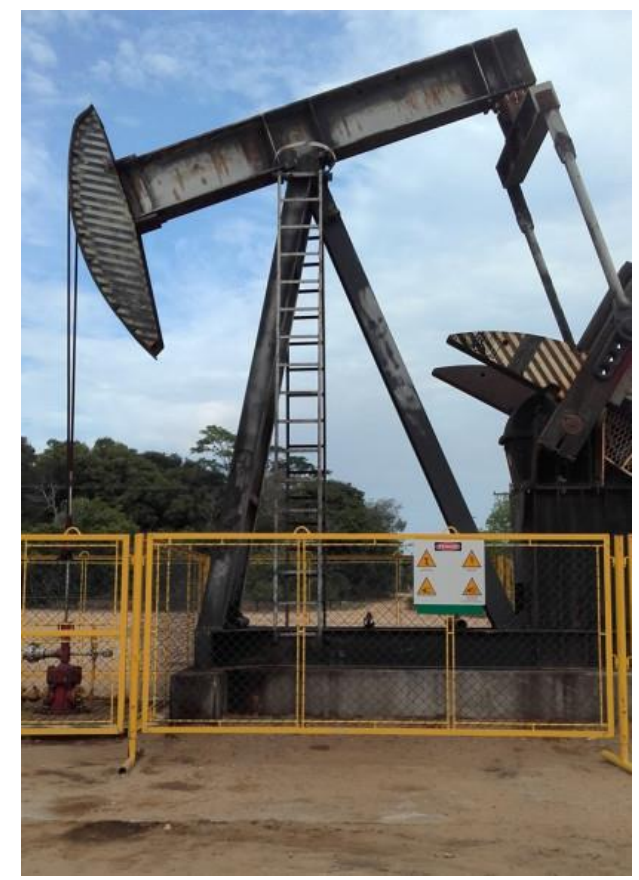

Figura 4: Bomba de sucção, ou "cavalinho" em Entre Rios.

Fevereiro, 2017.

Entretanto, o desastre sociotecnológico que fomos obrigadas a experienciar intensamente, e a contra gosto, deveu-se a atividades de extração de minério de ferro, efetuadas há mais de $600 \mathrm{~km}$ de distância via cursos de água, em Bento Rodrigues, Mariana, Minas Gerais. Em 5 de Novembro de 2015, uma barragem de rejeitos de mineração sob (ir)responsabilidade da Samarco Mineração S.A., um empreendimento conjunto da empresa Vale S.A. e da anglo-australiana BHP Billiton, colapsou. Cerca de duas semanas depois, rejeitos alcançaram a foz do rio Doce e o Oceano Atlântico. A trajetória da onda de lama, iniciada pela liquefação da barragem (CREADO \& HELMREICH, 2018), bem como suas consequências, têm sido desde então extensivamente documentadas e estudadas. ${ }^{5}$

5 Recomendamos especialmente os estudos desenvolvidos pelos grupos de estudos: Organon-UFES; Grupo de Estudos em Temáticas Ambientais (GESTA), ligado à Universidade Federal de Minas Gerais (UFMG); Grupo Política, Economia, Mineração, Ambiente e Sociedade (PoEMAS), vinculado à Universidade Federal de Juiz de Fora (UFJF). Além do próprio GEPPEDES-UFES.

Caderno Eletrônico de Ciências Sociais, Vitória, v. 8, n. 2, pp. 84-106, 2020. 


\section{Areal, Três Rios e Lagoa Parda}

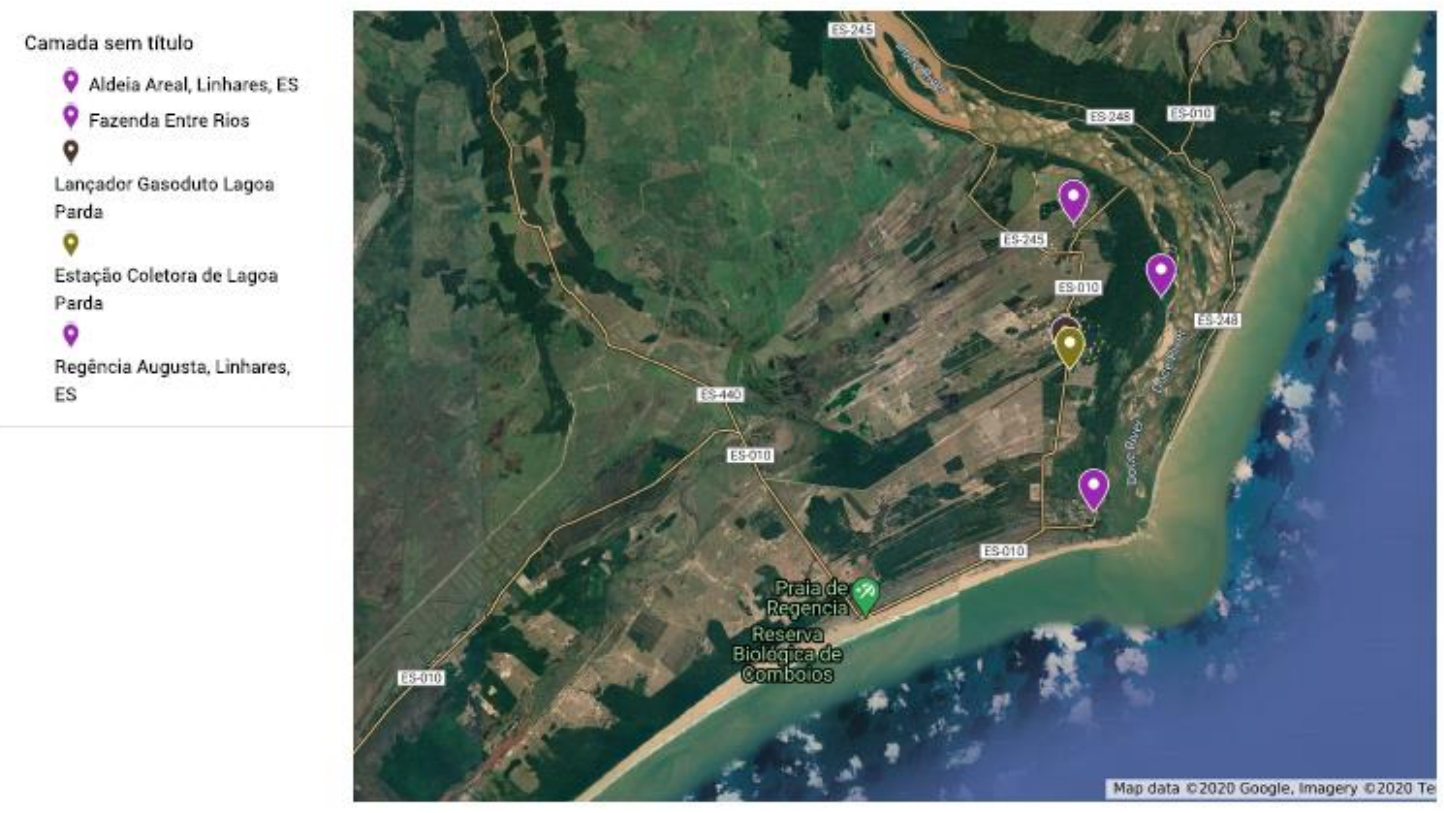

Figura 5: Imagem gerada a partir do Google Maps. 2020.

Em diálogo com Tsing e colaboradores (2017), tanto a exploração e distribuição de gás e óleo nas imediações de Regência Augusta, ES, quanto o crime-desastre da Samarco S.A. (e não de Mariana, MG) podem ser chamados de monstros. Por conta da monstruosidade mais recente, rejeitos de mineração alteraram as paisagens aquáticas, e as pessoas humanas que habitam próximas à foz do rio Doce passaram a lidar com alterações sensoriais evocando-as como: "lama da Samarco" ou "laranja Samarco" (SILVA, 2018; ARAÚjO, 2020); ou, como ouvimos em um encontro público com pescadores em Vitória, capital do ES, "lixo da Samarco" - aqui, em um esforço de distinção entre a lama considerada própria da foz e os rejeitos de mineração que vieram a se depositar no fundo do rio e do oceano. 

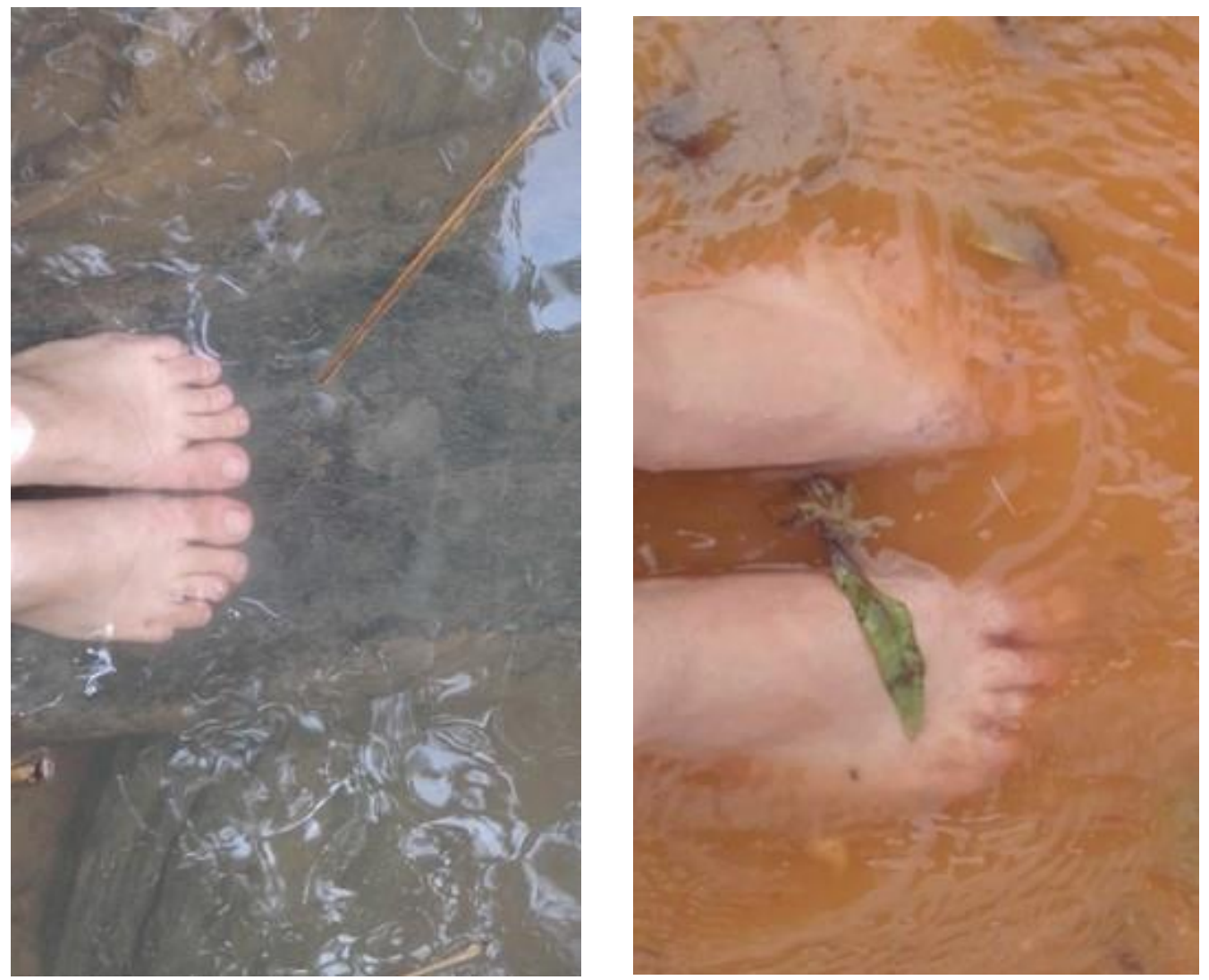

Figuras 6 e 7: Diferentes momentos do rio Doce. Em novembro de 2015, à esquerda, e em dezembro de 2015 , à direita. Fotos tiradas em expedição feita com GEPPEDES-UFES e Organon-UFES.

Por conta dos ciclos hidrológicos, a trajetória dos rejeitos via meios de comunicação tornou-se fonte de apreensão assim que houve o rompimento. Uma semana antes dos rejeitos (a)tingirem o Oceano Atlântico, ainda em novembro de 2015, as águas da foz do rio Doce estavam transparentes, como nas das proximidades da localidade de Entre Rios (Figura 6). O vídeo "Últimos dias em Regência", realizado por CAT-UFES e GEPPEDES-UFES, é um pequeno registro das (in)certezas daquele momento. ${ }^{6}$ As falas destacaram o momento de suspensão vivenciado, com queixas sobre a falta de comunicação do ocorrido e seus desdobramentos. Um comerciante colocou: "depois que acontecer o dano é que eles vão vim para tentar reparar" (GEPPEDES; CAT, 2015). Na espera de duas semanas, houve também quem achasse que a lama não chegaria mais (FONTINELLI, 2016).

Uma semana depois da chegada dos rejeitos e três semanas depois do rompimento rio acima, as águas estavam turvas (Figura 7) e com espuma no encontro de águas doces e salgadas (Figura 8).

\footnotetext{
${ }^{6}$ Disponível em: https://www.youtube.com/watch?v=cfFa_ybomiA\&t=5s (último acesso em 07 jul. 2021).
}

Caderno Eletrônico de Ciências Sociais, Vitória, v. 8, n. 2, pp. 84-106, 2020. 


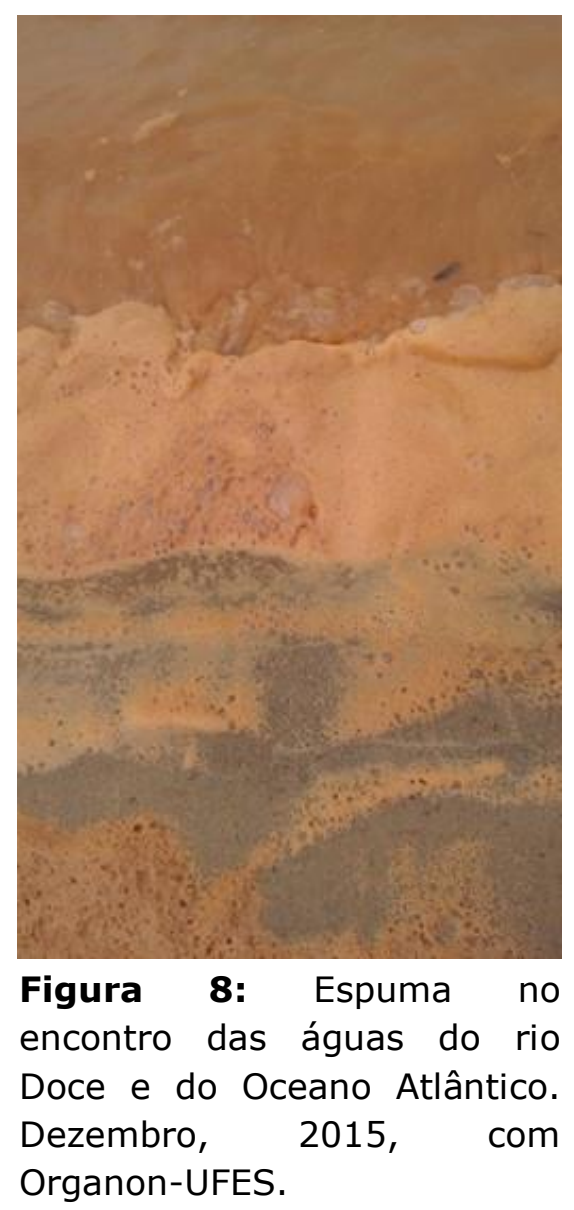

A espuma laranja, segundo moradoras/es, podia ser dispersada pelo vento ao secar. A dinâmica dos ventos nordeste e sul é muito conhecida pelos moradores do Espírito Santo como um todo, e o predomínio é do primeiro (FONTINELLI, 2016, pp. 172-172). Ouvimos também que a espuma, sua poeira, e, no geral, as águas turvas podiam irritar a pele e causar coceiras. Nesse contexto, muitos pararam de irrigar os cultivos, bem como de efetuar atividades domésticas, em especial aquelas que requerem ingestão (SILVA, 2018; SILVA; TORRES, 2018).

Sobre o consumo de peixes por moradoras/es, houve recomendações de valores máximos de ingestão diária, por conta de possíveis riscos à saúde humana no longo prazo. Uma delas foi feita pela Anvisa, em 2019, voltada para a avaliação de metais em animais aquáticos - e não nas águas ou nos sedimentos. Os estudos foram realizados por outros, com mediação do Instituto Chico Mendes de Conservação da Biodiversidade (ICMBio) e da Fundação Renova. ${ }^{7}$ Apesar das limitações, tanto no que diz respeito às complexidades do

\footnotetext{
${ }^{7}$ Fundação criada em 2016, por meio de um acordo judicial chamado Termo de Transação e Ajustamento de Conduta (TTAC) com a justificativa de lidar com as consequências do rompimento. Muitas são as controvérsias sobre sua criação e modo de operar.
}

Caderno Eletrônico de Ciências Sociais, Vitória, v. 8, n. 2, pp. 84-106, 2020. 
assunto quanto aos problemas nos próprios materiais disponibilizados, ${ }^{8}$ a nota apontou altos índices dos seguintes metais não essenciais: (1) cádmio, principalmente em peixes de água salgada e em crustáceos; (2) mercúrio, sobretudo nos peixes de água doce; (3) chumbo, em peixes de água salgada. Dos três, chumbo e mercúrio "apresentam maior preocupação à saúde humana" (SEI/ANVISA, 2019, p. 13). ${ }^{9}$ A nota sugeriu um consumo diário máximo de 200 gramas de carne de peixe para adultos e 50 gramas para as crianças. ${ }^{10}$

No geral, as atividades de pesca foram impactadas significativamente, sobretudo nos primeiros anos após o ocorrido. A pesca tem muita importância na vila, compondo relações locais e não locais, muitas vezes sem uso de moeda (LEONARDO et al., 2017). Tanto que, ao serem questionadas/os sobre a toxicidade das águas, falas de moradoras/es, ouvidas entre 2015 e 2017, conjugavam-se a diversos temas e incertezas, com pronunciada ênfase nas associações e preocupações com o alimento e seus preparos (SILVA, 2018; SILVA; TORRES, 2018). Como até hoje não houve a restauração das condições de vida anteriores, as "relações viscerais e emocionais com o pescado" (SILVA; TORRES, 2018, p. 193), ${ }^{11}$ assim como outros engajamentos corporais com o pescar, continuaram relevantes em Regência Augusta, apesar dos riscos e receios intuídos.

Quanto às águas, novas aparições do tom alaranjado foram testemunhadas em outras ocasiões. Isso porque quando chove nas partes mais altas do rio Doce, o "laranja Samarco" domina a paisagem novamente. Não se

\footnotetext{
${ }^{8}$ A nota registra que, quanto ao chumbo, em peixes de água doce, os dados da Fundação Renova foram insuficientes, por uso de metodologia inadequada, com comprometimento de $50 \%$ das amostras.

${ }^{9}$ Os metais não essenciais são definidos em contraste com os metais essenciais. Enquanto os metais essenciais são necessários ao corpo humano, conformando 25 elementos químicos, 21 deles ingeridos pela dieta; os não essenciais não o são (SEI/ANVISA, 2019).

${ }_{10}$ NOTA TÉCNICA No. 8/ 2019/SEI/GEARE/GGALI/DIRE2/ANVISA. Quando da primeira versão deste texto, a nota estava disponível em: http://portal.anvisa.gov.br/noticias//asset_publisher/FXrpx9qY7FbU/content/peixe-do-rio-doce-deve-ser-consumido-commoderacao/219201, acessível em formato pdf. Em junho de 2021, quando confeccionamos a presente versão, o link nos direcionou para a página principal da Anvisa: https://www.gov.br/anvisa/pt-br. Em pesquisa no site da Anvisa, encontramos notícia com data de 17 de julho de 2019: "Peixe do rio Doce: riscos do consumo Anvisa avaliou dados coletados sobre presença de metais em pescados na foz e na bacia do rio Doce Concentrações de chumbo e mercúrio são as mais preocupantes", no hiperlink https://www.gov.br/anvisa/pt-br/assuntos/noticias-anvisa/2019/peixe-do-rio-doce-riscosdo-consumo. Ao final, um link indicava a nota, todavia, ao se clicar nele, adveio um arquivo do tipo: "application/octet-stream (36 bytes)". Feito o download, o formato do arquivo não foi reconhecido. À semelhança do que temos visto a partir de outros estudos, há um contínuo processo de descontaminação simbólica do ocorrido também a partir do meio online (ARAÚJO, 2020). Os próprios moradores atingidos reclamam de dificuldades no acesso a informações (SILVA, 2010; SILVA, 2018; SILVA; TORRES, 2018; ARAÚJO, 2020).

${ }^{11}$ A terminologia usada recebeu influência de textos do prof. Dr. Renzo Taddei.
} 
tratou de um evento isolado, mas sim um crime-desastre contínuo (CREADO; HELMREICH, 2018) (Figuras 9, 10, 11 e 12). Justamente por isso o termo crime foi muito utilizado pelas pessoas atingidas, em posicionamentos que acompanhamos em algumas das arenas públicas que contaram com a presença de moradores da região e que foram abertas à ampla participação.
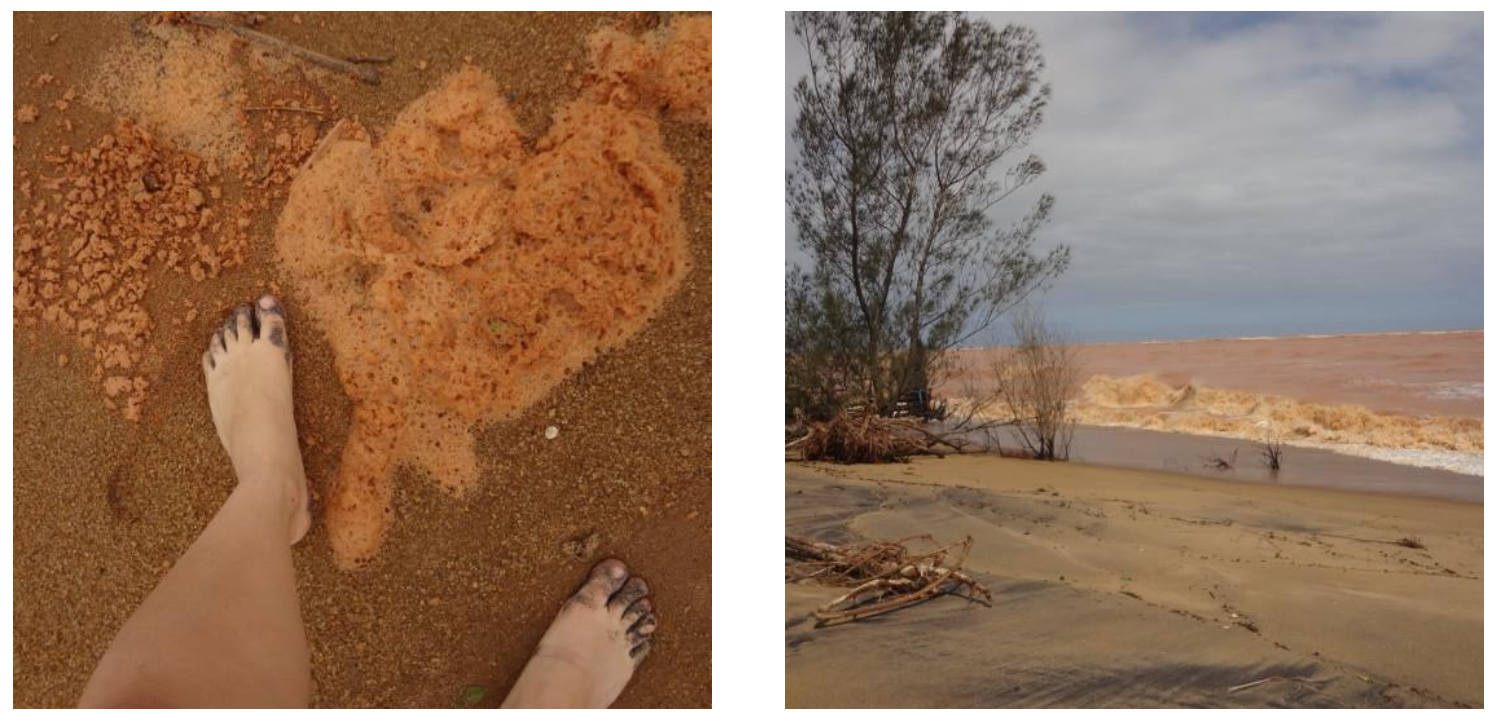

Figuras 9 e 10: Distintos momentos do "laranja Samarco" e sua espuma; novembro de 2016, com GEPPEDES-UFES: à esquerda, espuma formada no encontro das águas doces e salgadas; à direita, praia de Comboios.
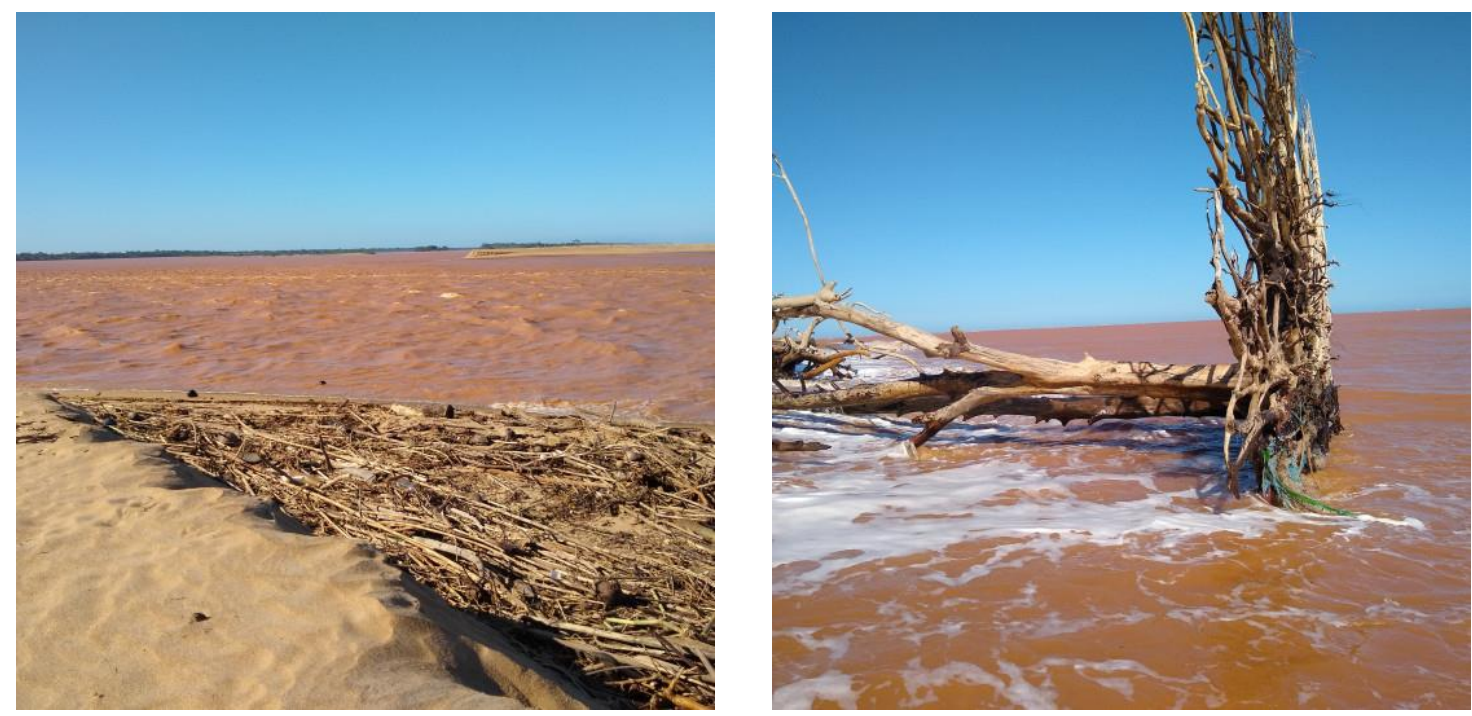

Figuras 11 e 12: Distintos momentos do "laranja Samarco" e sua espuma; fevereiro de 2020: à esquerda, foz do rio Doce; à direita, praia de Comboios. As duas imagens trazem resultados de alguns dias de chuva à montante. Os dias de maior turbidez tinham ocorrido antes, como nos foi dito.

Os usos de águas doces e oceânicas, e de seus seres, trouxeram à superfície dúvidas sobre a qualidade das águas subterrâneas. Isso nos coloca a existência de uma multiplicidade material-simbiótica aquática, como 
destacaram Silva (2018) e Ballestero (2019). A primeira com seu estudo ligado à própria região da foz do rio Doce, e a segunda, trazendo-nos análises de dispositivos técnico-jurídicos da Costa Rica e do Brasil. ${ }^{12}$ A multiplicidade nas águas em Regência Augusta, nos leva de volta às primeiras linhas e fotografias deste texto, bem como às preocupações iniciais do programa integrado de pesquisa e extensão de que fizemos parte entre 2015 e 2018.

Tão logo os rejeitos de mineração chegaram, algumas/ns moradoras/es, apreensivas/os sobre a qualidade das águas servidas na vila, perfuraram o solo, ou reabriram antigos poços. Ao fazer isso, elas/es (re)tomaram o contato com os odores de óleo mineral, e concluíram que as águas subterrâneas não poderiam substituir as águas do rio Doce; e, antes, configurariam como outra fonte de provável contaminação. Muitas/os moradoras/es acreditam que a causa principal para tais alterações seriam a extração e a distribuição de óleo. Por outro lado, ouvimos técnicos governamentais dizendo que tais características sensoriais seriam naturais. Uma posição que evita, de antemão, confrontações com as/os envolvidas/os direta e indiretamente na atividade extrativa, com significativos capitais políticos e econômicos.

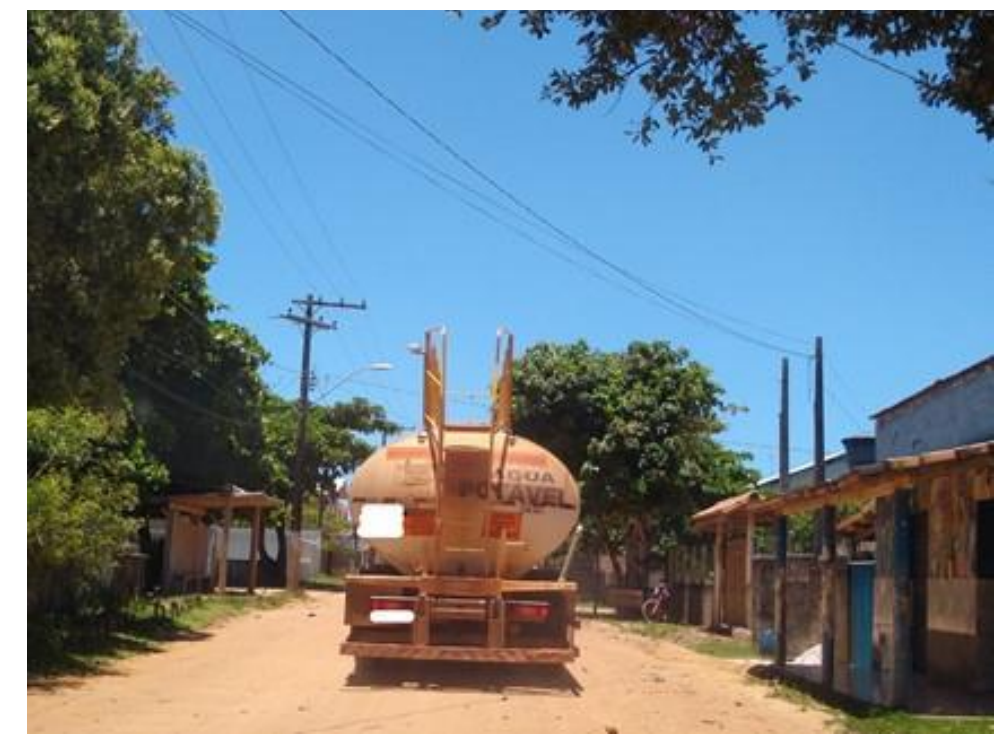

Figura 13: Caminhão com água potável adentra a vila de Regência Augusta. Fevereiro, 2020.

No Espírito Santo e em Minas Gerais, o poder dos empreendimentos de mineração e parceiros fazem-se sentir no dia-a-dia e no meio político. Embora pouco frequentes, alguns ruídos a respeito deles podem ser ouvidos. Um

\footnotetext{
${ }^{12}$ A saber: uma fórmula que embasa as contas de água, um índice, uma lista e um pacto. Os três primeiros dispositivos desenvolvidos na Costa Rica e o último, no Brasil. Agradeço à profa. Dra. Catarina Morawska pela indicação da leitura; possíveis incorreções de leitura são minhas. Aprendemos também com Sampaio do Nascimento (2020) que a multiplicidade das águas se faz presente nos rituais da Umbanda.
}

Caderno Eletrônico de Ciências Sociais, Vitória, v. 8, n. 2, pp. 84-106, 2020. 
exemplo, foi a inauguração de um parque, nas proximidades do Porto de Tubarão, também na capital do Espírito Santo, Vitória. O porto é usado de modo consorciado pela Vale S.A. com outras empresas, e, através dele, muito do minério de ferro produzido em Minas Gerais, segue para outras partes do Brasil e, sobretudo, do mundo. A festa de inauguração do parque em 2019 foi cancelada por conta do rompimento de outra barragem sob controle da Vale S.A., em Brumadinho, MG, ocorrido em 25 de janeiro de 2019. Houve pequena manifestação em frente à área, quando de sua abertura ao público. $O$ parque estava repleto de adultos com crianças brincando, enquanto vozes humanas saídas de um carro de som (re)lembravam que a empresa envolvida na construção da área associava-se aos dois maiores rompimentos de barragens no Brasil, e no mundo.

O parque atrai muitas crianças e adultos nos finais de semana, além de comerciantes os mais variados. Sua existência serve de lembrete dos tentáculos do capitalismo em nossos cotidianos: o parque resultou também de um Termo de Compromisso, assinado entre a empresa, os ministérios públicos federal e estadual e os governos estadual e municipal, por conta do minério de ferro que cai nas águas oceânicas a partir das esteiras que levam o minério até os navios. ${ }^{13}$ Aqui, convergindo com a fala do comerciante entrevistado em Regência Augusta, pouco antes da chegada dos rejeitos de mineração na foz do rio Doce, em novembro de 2015, a preocupação dá-se após a dano, ao invés ele ser evitado. São atos sequenciais de apropriação através da poluição nas duas situações: espalhamento de dejetos seguido de pagamentos (SERRES, 2011). ${ }^{14}$

${ }^{13}$ Como o noticiado, por exemplo, em: https://esbrasil.com.br/camburi-atlantica-parque/ (último acesso em 22/06/2021); https://www.agazeta.com.br/colunas/leonel-ximenes/valecancela-festa-de-inauguracao-de-parque-em-camburi-0119 (último acesso em 22/06/2021).

${ }^{14}$ Para Serres (2011), há uma equivalência excrementícia na equação poluidor-pagador.

Caderno Eletrônico de Ciências Sociais, Vitória, v. 8, n. 2, pp. 84-106, 2020. 


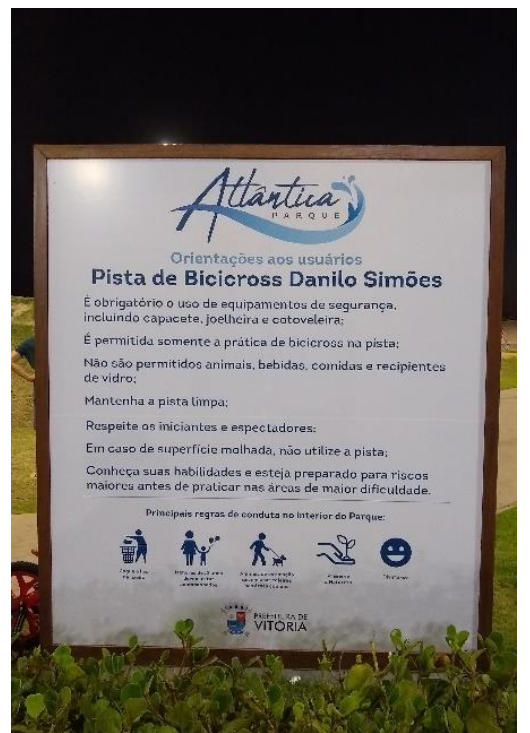

Figura 14: Placa Atlântica Parque, Vitória, ES. Agosto, 2019.

Destacamos, a seguir, a frase de um anúncio visto no aeroporto de Vitória em julho de 2019: "Nós transformamos o aço, o aço nos transforma". Uma sentença ligada à ontologia da mineração. Ela carrega insensibilidade e sarcasmo para quem minimamente acompanhou os desastres de 2015 e de 2019, ou ao menos um deles.

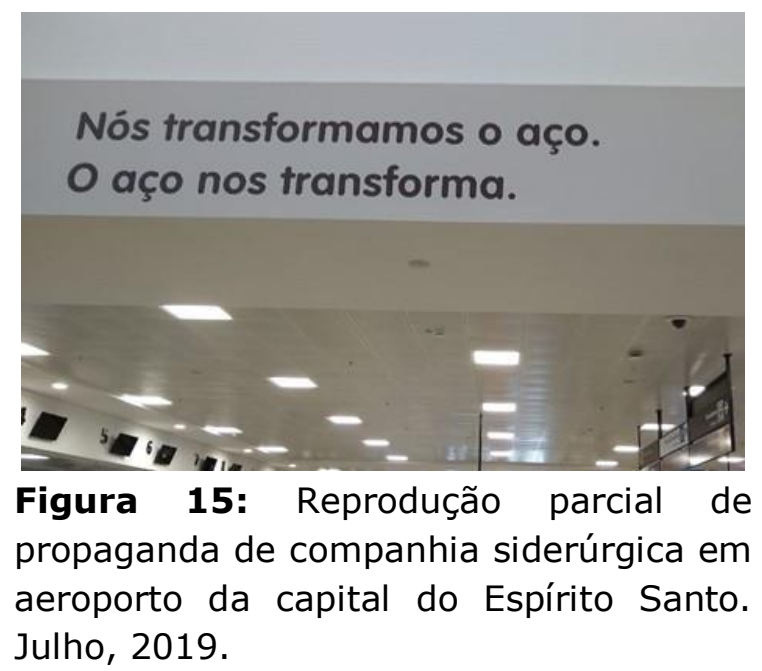

Podemos refletir sobre tais vínculos, a partir de perguntas que emergem da frase da figura acima: Até onde a exploração minerária e o consumo de itens que contam com seu aporte transformam nosso (e outros) agenciamentos? E se não estivermos satisfeitas com o que nos tornamos e com o que tem sido feito de mundos humanos e mais do que humanos a partir disso? Poderíamos ser menos dependentes de relações, produtos, serviços e pagamentos resultantes da mineração? 
Não é nossa pretensão responder a essas questões de forma teóricoespeculativa aqui. O ressaltamos é que são preocupações sobre as quais algumas pessoas humanas que vivem e ou trabalham em Regência Augusta possuem. Elas compõem redes que buscam conectar o local e o não-local, e, às vezes, o material e o espiritual, em busca de alternativas. Tentam construir outras relações com a $\mathrm{T} /$ terra e seus contextos de dor, (re)criar formas de vida coletivas e individuais para viver em e com mundos e seres menos arruinados. Podem não conformar um grupo numeroso, e até mesmo ter alguns vieses de classe e étnicos, mas tentam pensar e colocar em prática mudanças em seus estilos de vida, dando atenção a suas relações com plantas, T/erra, alimentos, águas, ondas, entes, produções artísticas e artefatos (SILVA, 2021). Ao mesmo tempo, reconhecem a forte e indesejada presença dos rejeitos de mineração nas águas e nos solos, assim como dos rejeitos ligados à exploração de gás e óleo; bem como em diferentes corpos, unidos a partir de relações viscerais, como as estabelecidas pela alimentação (TADDEI, 2014; ALAIMO, 2017).

São projetos "não inocentes", nos termos de Donna Haraway (2016), pois objetivam opções econômicas para a vila e seus habitantes, cujas águas e cujos seres aquáticos constituem principais fontes de renda, através da pesca, do surfe, ou do turismo no verão ou nas festas culturais. Porém, combinam preocupações econômicas com outros valores e iniciativas, visando a valorização cultural, a regeneração ambiental ou o cuidado com as/os mais vulneráveis (SILVA, 2018; 2021). Existem, então, diferentes tipos de não inocência; mais ou menos suspeitos, mais ou menos cruéis... O quão não inocentes são esses projetos diante de outros desempenhados na região antes e depois do rompimento da barragem?

Os dutos de óleo e de gás espalhados pela paisagem nas proximidades da foz do rio Doce, assim como o "laranja Samarco" são testemunhos e lembretes de opções monstruosas, perante às quais outras alternativas são buscadas. Elas possuem importância, mesmo que relativa, por demonstrarem possibilidades de (re)invenção, em cenários de destruições cumulativas. E contar essas estórias é importante também (HARAWAY, 2006; TSING, 2019), mesmo que não expliquem tudo.

Ao tentarmos tratar as iniciativas dessas/es nossas/os interlocutoras/es com admiração e respeito, como Ballestero (2019) e Merlo de Souza (2020) fizeram em outros contextos, tentamos restaurar as esperanças de moradoras/es, mas também de outras/os, incluindo nossas próprias. Mesmo que sejam esperanças (a)tingidas de tons de "laranja Samarco", podemos tentar criar outros tons e estórias significativos com a/s mesma/s T/terra/s e seus seres.

Caderno Eletrônico de Ciências Sociais, Vitória, v. 8, n. 2, pp. 84-106, 2020. 
Nesse contexto, a produção de artefatos de barro ganha significado especial, como a ressaltar as finitudes da vida e de uma política baseada na expansão ilimitada de territórios (LATOUR, 2020). A edição do texto de Latour (2020) traz fotografias de potes de barro, da exposição Habitável, em que se permitiu aos expectadores tornarem-se guardiões dos recipientes, ao poderem levar os potes consigo. A referência a seres ctônicos aparece também em Haraway (2006). E havíamos recebido ainda uma advertência, em 2017, de que a lama, para alguns coletivos ceramistas, possui conotações positivas; em contraste com o uso do termo que reforça as negatividades dos rejeitos de mineração da Samarco S.A. ${ }^{15}$

Os utensílios de barro apareceram em Regência Augusta para nós na atuação do Coletivo Ceramística, sediado na foz do rio Doce. Seus potes foramnos apresentados em 2017 (Figuras 16 e 17), e postos em diálogo com a presença de povos indígenas no território.

Material-e-simbolicamente a apresentação em sequência de potes arqueológicos (quebrados ou não) ou novos (concluídos com sucesso ou inconclusos) (Figuras 16 e 17) foi uma intervenção a ressaltar perdas-eregenerações e a remontar presenças conjuntas, passadas-presentes-e-futuras. o Coletivo Ceramística atua com outros coletivos envolvidos em práticas de regeneração no rio Doce (ver também SILVA, 2021), e endossa reivindicações (d)e existências humanas-mas-não-apenas (Figuras 18 e 19) como a de Areal, que, apesar de cercada por dutos e bombas de sucção, demanda do Estado brasileiro seu reconhecimento como terra indígena. ${ }^{16}$

\footnotetext{
${ }^{15}$ Comunicação oral de Bianca Pavan Piccoli, 2017.

${ }^{16}$ Há uma reportagem que registra a autoidentificação de Areal como comunidade indígena, bem como uma manifestação realizada em janeiro de 2019 , solicitando que a Petrobrás efetuasse compensação financeira pela exploração de óleo em seu território. Na primeira versão deste texto a reportagem estava disponível em: https://seculodiario.com.br/public/jornal/materia/indigenas-de-areal-cobram-divida-de-40anos-da-petrobras. No entanto, durante a produção de versão em português, não encontramos mais a notícia nesse sítio eletrônico. Todavia, ela estava salva no site Combate Racismo Ambiental: https://racismoambiental.net.br/2019/01/07/indigenas-de-arealcobram-divida-de-40-anos-da-petrobras/, acesso em 14/06/2021.
} 


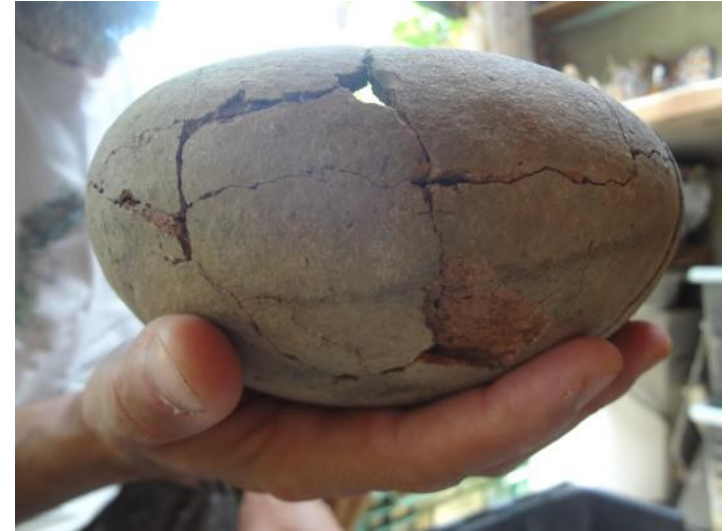

Figuras 16 e 17: Peças mostradas Fevereiro, 2017, com GEPPEDES-UFES.

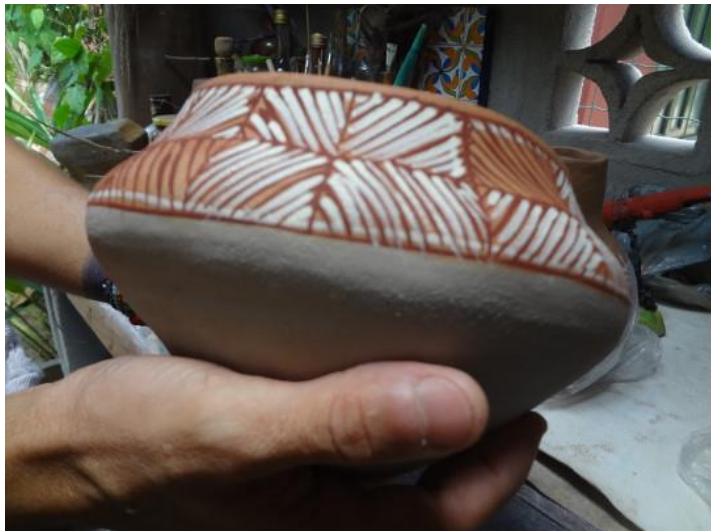
por membro do Coletivo Ceramística.

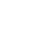

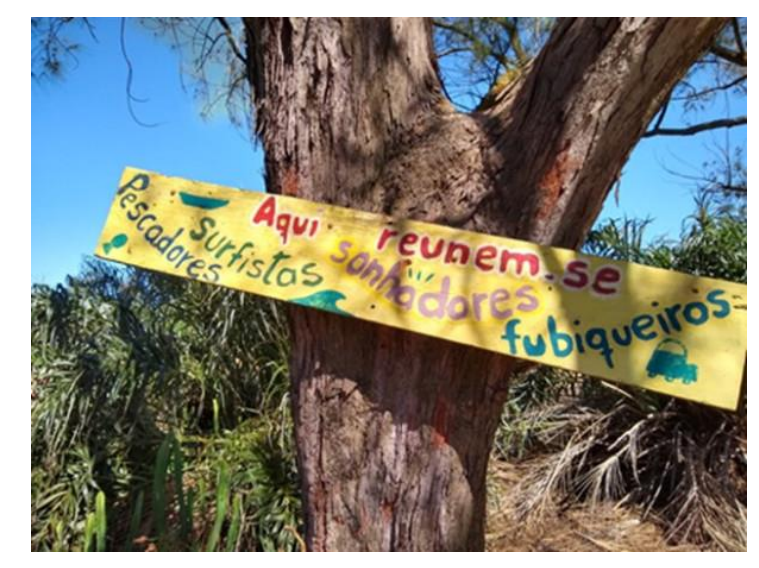

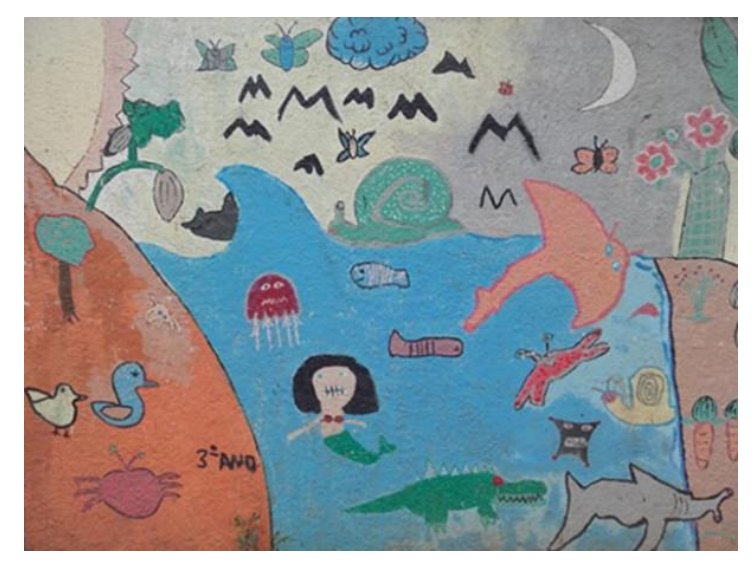

Figuras 18 e 19: Esforços de regeneração na foz do rio Doce: à esquerda, placa na praia, logo em frente à vila de Regência Augusta, em fevereiro de 2020; à direita, pintura em muro da escola, elaborada por crianças do $3^{\circ}$. Ano, em outubro de 2017, com GEPPEDES-UFES.

Como Regência Augusta é também frequentada por surfistas e foliões, a chegada e a presença de rejeitos afetaram também o turismo. Em fevereiro de 2020, na praia, em frente à vila, uma placa buscava reiterar essas presenças: "Aqui, sonhadores - pescadores, surfistas e "fubiqueiros" encontram-se" (Figura 18). Observamos que Fubica é o nome do carro de som que circula no Carnaval. Se lidas em outras ordens, as palavras não mudam muito o sentido mais amplo da frase, porém permitem distintas ênfases a diferentes agentes humanos. Quanto à força de águas doces e salgadas e aos seus entes, pinturas ainda recentes em 2017 no muro da escola traziam sua importância, bem como 
abalos trazidos pelos rejeitos de mineração. Sob uma camada alaranjada de poeira, a pintura da figura 19 ainda era identificável em fevereiro de $2020 .{ }^{17}$

Dentre os seres aquáticos, as tartarugas marinhas continuam como animais emblemáticos importantes nos enredamentos que ligam Regência Augusta, seus habitantes humanos e não-humanos, e o ambientalismo, em especial na sua conformação em projetos de conservação. As iniciativas a elas devotadas persistiam nas areias de Comboios, em fevereiro de 2020, via marcação e proteção de ninhos. A atuação do projeto também influenciou algumas das medidas tomadas no contexto pós-crime-desastre, ocorrido em 2015, e que são relevantes até hoje. Aqui alguns dos tentáculos do capitalismo também emergem, o que complexifica as configurações relacionais, permitindonos novamente evidenciar a presença da equação poluidor-pagador vinculando extrativismos minerários e iniciativas ambientalistas, tanto por conta dos financiamentos ao projeto a partir de empreendimento petroleiro quanto por conta de medidas de compensação por parte da Samarco S.A. (FONTINELLI; CREADO, 2020). Ao apontar isso não desejamos reduzir as inciativas a esses vínculos.

Das espécies que desovam ali, a cabeçuda (Caretta caretta) e a gigante ou de couro (Dermochelys coriacea), a segunda é fonte de maior preocupação, pois sua população do sudoeste do Atlântico Sul consta como criticamente ameaçada na lista vermelha da União Internacional para a Conservação da Natureza (UICN). ${ }^{18}$ Como a desafiar todas as perdas, na noite e na manhã antes da chegada dos rejeitos de mineração na foz do rio Doce, Povoação, vila que fica na outra margem do rio Doce, também na outra margem do rio, recebeu muitas desovas com: 15 tartarugas em flagrantes de desova, e 35 ninhos identificados, "parecia que as tartarugas sabiam o que aconteceria e aproveitaram para desovar" (FONTINELLI, 2016, p. 170).

Esperamos que a resiliência das tartarugas marinhas atribuídas a elas pelos naturalistas, mas não atribuída a outros seres aquáticos, possa-nos trazer algum alento, e servir de inspiração para nos desviarmos um pouco mais de lamas de dejetos.

\footnotetext{
${ }^{17}$ A foto da pintura (Figura 19) foi publicada também em Trigueiro e colaboradores (2018).

${ }^{18}$ Veja também Torres e colaboradores (2017) e o site do próprio Tamar, que menciona as cinco espécies de tartarugas marinhas encontradas no Brasil: https://www.tamar.org.br/especies.php?cod=98 (último acesso 14/06/2021). Já a população da cabeçuda que desova ali consta com o status de menos preocupante. A lista da UICN, está disponível em https://www.iucnredlist.org (último acesso em 09/07/2021).
}

Caderno Eletrônico de Ciências Sociais, Vitória, v. 8, n. 2, pp. 84-106, 2020. 


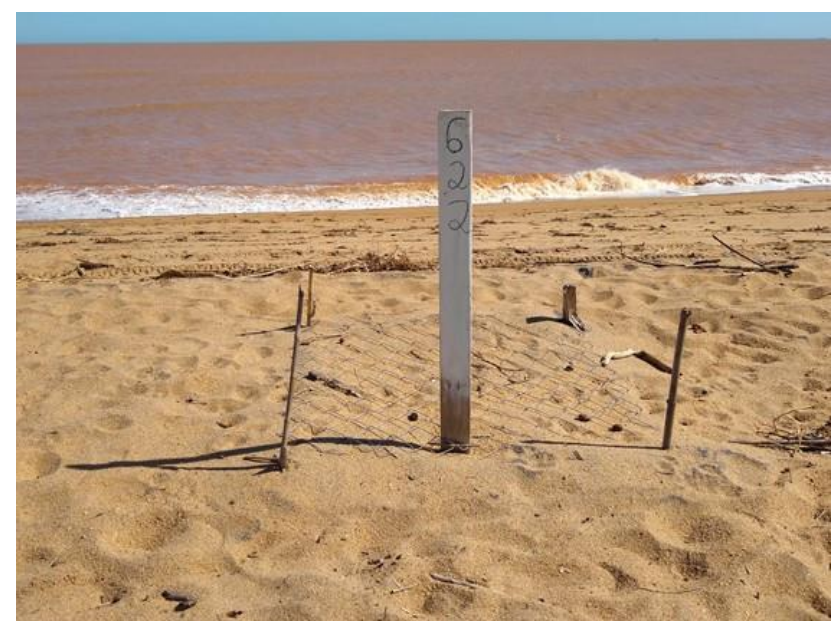

Figura 20: Ninho de tartaruga marinha monitorado por projeto de conservação, ao fundo 0 "laranja Samarco". Fevereiro de 2020.

\section{Posfácio}

O texto foi redigido a partir de convites para escrevermos algo sucinto, com liberdade de escrita. Em primeiro momento, pensamos em escrever antes de colocar as imagens. Não funcionou. Invertemos o processo, até para lidar com resistências afetivas. Após, sentimos a necessidade de revisitar Regência Augusta, pois nem todas as imagens acumuladas deram conta do que 0 escrever exigia. O retorno foi em fevereiro de 2020, depois de cerca de dois anos sem ir à vila; o que nos trouxe a ânsia de voltar. Infelizmente, com a pandemia da Covid-19, medidas de isolamento social iniciaram-se e não pudemos fazer isso. Certamente a pandemia agravou algumas dificuldades vividas na foz do rio Doce.

Gostaríamos ainda de usar mais esse espaço para refletir sobre (des)encaixes entre imagens e palavras neste texto. Pessoas humanas emergem mais das palavras do que das imagens. Há várias razões para tal, para além da timidez da autora. Uma delas é que as/os moradoras/es da vila foram abordadas/os das mais diferentes formas ao longo do tempo, desde a década de 1980, algo intensificado desde a chegada dos rejeitos de mineração, o que se colocou como um problema até para a consecução de pesquisas iniciadas ali previamente ao desastre. Mesmo antes, por conta de outras dinâmicas, existiam dificuldades nesse sentido, fosse com abordagens mais coletivas, fosse com técnicas mais clássicas de investigação como gravação de entrevistas.

O nosso desconforto com isso só aumentou com o tempo. Fotografar mais as presenças não-humanas com indícios dos humanos foi um meio de lidar com ele. Não tivemos uma preocupação estética com o desastre, nem com uma

Caderno Eletrônico de Ciências Sociais, Vitória, v. 8, n. 2, pp. 84-106, 2020. 
abordagem apelativa, como o colocado em Vasco (2018), para fotógrafos e jornalistas, respectivamente. ${ }^{19}$ Acreditamos que as imagens, mesmo sem as pessoas humanas em primeiro plano, não deixam de contar com suas presenças, pois os dejetos demarcam e apropriam territórios (SERRES, 2011). Mas pensamos também que as imagens trazem indícios outros, como algumas criações humanas.

É importante ter-se em mente outra problematização trazida por Ballestero (2019) para o caso da Costa Rica. Para ela, reimaginar materialidades "não é um projeto intrinsicamente mais democrático, decolonial, não-neoliberal, não-patriarcal" (BALLESTERO, 2019, p. 141). Seu estudo coloca que as especificidades aquáticas, inclusive, foram utilizadas em discussões políticas, de modo a impedir a aprovação de emendas constitucionais que visavam o reconhecimento da água como um bem público, e não apenas direito humano, transformação que almejava evitar uma futura privatização da(s) água(s) na Costa Rica. ${ }^{20} \mathrm{O}$ recurso à diversidade aquática teria posto em relevo as dificuldades tecno-jurídicas e políticas de lidar com sua fluidez, bem como limites das convenções ontológicas usadas. Para Ballestero (2019) não apenas os enredamentos, mas também as separações são importantes para se pensar e agir politicamente.

\section{Referências bibliográficas}

ALAIMO, Stacy. 2017. Feminismos transcorpóreos e o espaço ético da natureza. Rev. Estud. Fem., Ago, vol.25, no.2, pp. 909-934. DOI: http://dx.doi.org/10.1590/1806-9584.2017v25n2p909 .

ARAÚJO, Giovana M. 2020. Humanos e não-humanos: para um debate acerca das relações entre afetados pelo crime-desastre da Samarco e o rio Doce a partir de materiais textuais e imagéticos. Monografia, DCSo-UFES, Vitória. $70 \mathrm{p}$.

BALLESTERO, Andrea. A future history of water. Durham, London: Duke University Press, 2019. 232p.

\footnotetext{
${ }^{19}$ Vasco (2018) optou por deformar e efetuar montagens com imagens. A mesma também destacou problema no uso de imagens de satélite, por seu olhar distanciado e de cima para baixo. Nosso uso da figura 5 tentou dialogar com essa observação: (1) ao destacar apenas a foz do rio Doce, e, ao mesmo tempo, reconhecer que tais imagens são importantes para aqueles que atuam, por exemplo, nas políticas públicas; (2) ao articular a figura $5 \mathrm{com}$ as demais imagens que, por sua vez, remetem ao deslocamento por terra.

20 Ballestero (2019, pp. 109-143) analisou discursos proferidos entre 2002 e 2013, chegando a uma lista com 30 tipos de águas.
}

Caderno Eletrônico de Ciências Sociais, Vitória, v. 8, n. 2, pp. 84-106, 2020. 
CREADO, Eliana S. J.; HELMREICH, Stefan. 2018. A wave of mud: the travel of toxic water from Bento Rodrigues to the Brazilian Atlantic. Rev. Inst. Estud. Bras., SP, n. 69, pp. 33-51, Apr. DOI: https://doi.org/10.11606/issn.2316901X.v0i69p33-51.

CREADO, Eliana S. J. et al. 2018. Vidas de rio e de mar: pesca, desenvolvimentismo e ambientalização. 1. ed. Vitória: ProEx, v. 1. 300p.

FONTINELLI, Davi S. 2016. Santa Tartaruga! Invenções e mudanças ontológicas no litoral norte do Espírito Santo. Mestrado em Ciências Sociais, PGCSUFES, Vitória. 251p.

FONTINELLI, Davi S.; CREADO, Eliana S. J. 2020. From food to offspring: engagement between humans and sea turtles in two communities on the north coast of Espírito. Vibrant: Virtual Brazilian Anthropology, v. 17. Disponível em: https://doi.org/10.1590/1809-43412020v17a351 . Acesso em: 09 jul. 2021. 20p.

HARAWAY, Donna J. 2016. Staying with the trouble. Durham; London: Duke University Press. 296p.

LATOUR, Bruno. 2020. Onde aterrar? Piseagrama, Belo Horizonte, número 14, pp. 100-109. Disponível em: https://piseagrama.org/onde-aterrar/ . Acesso em: 09 jul. 2021.

LEONARDO, F. et al. Rompimento da barragem de Fundão (Samarco/Vale/BHP Billiton) e os efeitos do desastre na foz do rio Doce, distritos de Regência e Povoação (ES). Relatório de Pesquisa. Vitória: GEPPEDES-UFES, 2017. $114 \mathrm{p}$.

MERLO de SOUZA, Gabrielly. Envolver o que nos envolve: Permacultura e sítios ecológicos em paisagens multiespécies na Serra do Espinhaço. 2020. Tese (Doutorado em Antropologia). BH, MG: UFMG. 383 p.

SAMPAIO DO NASCIMENTO, Maria. 2020. Espíritos Afrodiaspóricos Pretos Velhos: cura e legado Bantu. Projeto de pesquisa. 15p.

SERRES, Michel. 2011. O mal limpo: poluir para se apropriar? Rio de Janeiro: Bertrand Brasil. 110p.

SILVA, Bianca S. 2021. Abordagem de convivencialidade aplicada à regeneração de paisagens alteradas após o desastre do rio Doce. No prelo. 22p.

SILVA, Bianca J. 2018. "A lama que rolou de cima": alguns desdobramentos sociopolíticos e sociotécnicos sobre as águas do Rio Doce e do Oceano 
Atlântico após a chegada dos rejeitos de mineração da Samarco na foz do Rio Doce - ES. Dissertação, PGCS-UFES, Vitória. 166p.

SILVA, Bianca S.; TORRES, Clara Crizio de A. 2018. A alimentação enquanto relação visceral com o pescado na vila de Regência e algumas pontuações sobre os seus desvios pós-lama da Samarco. CREADO, Eliana S. J. et al. 2018. Vidas de rio e de mar: pesca, desenvolvimentismo e ambientalização. 1. ed. Vitória: ProEx, v. 1, pp. 181-208.

SILVA, Telma C. 2010. Eventos críticos: sobreviventes, narrativas, testemunhos e silêncios. Trabalho apresentado na 27 a Reunião Brasileira de Antropologia, realizada entre os dias 01 a 04 de agosto de 2010, Belém, Pará, Brasil.

TADDEI, Renzo. Ser-estar no sertão: capítulos da vida como filosofia visceral. Interface - Comunicação, Saúde, Educação. 2014, v. 18, n. 50, pp. 597607. Disponível em: <https://doi.org/10.1590/1807-57622013.0777> . Acesso em: 22 jun. 2021.

TADDEI, Renzo. The field of Anthropology of disasters in Brazil: challenges and perspectives. In: GARCÍA-ACOSTA, Virginia (ed.). The Anthropology of disasters in Latin American: state of the art. London, New York: Routledge, 2020, pp. 45-62.

TORRES, C. C. A.; CREADO, E. S. J.; CAMPOS, A. C.; FREITAS, P. L. T. 2017. Repertórios em rede: o caso da mobilização de duas espécies de tartarugas marinhas em uma ação civil pública. Vivência: Revista de Antropologia, v. 1, pp. 75-96. Disponível em: https://periodicos.ufrn.br/vivencia/article/view/12827. Acesso em 22 jun 2021.

TRIGUEIRO, Aline et al. 2018. Encontros de rios e mar: áreas protegidas e grandes projetos de desenvolvimento em Barra do Riacho e Regência Augusta (ES). Vitória, ES: ProEx, v. 1. 36p.

TSING, Anna L. et al. 2017. Arts of Living on a Damaged Planet: Monsters and Ghosts. Minneapolis: University of Minnesota Press.

TSING, Anna L. 2019. Viver nas ruínas: paisagens multiespécies no Antropoceno. Brasília: IEB Mil Folhas. 281p.

VASCO, Marcela. 2018. A representação da tragédia de Mariana: fotografias enterradas e imagens sobreviventes. Giz - Gesto, Imagem e Som, São Paulo, v. 3, n. 1, pp. 203-217, jul. DOI: https://doi.org/10.11606/issn.2525-3123.gis.2018.142387 . Acesso em: 12 jul. 2021.

Caderno Eletrônico de Ciências Sociais, Vitória, v. 8, n. 2, pp. 84-106, 2020. 
ZHOURI, Andrea et al. 2017. The Rio Doce Mining Disaster in Brazil: between policies of reparation and the politics of affectations, in: Vibrant, v. 14, n. 2. August. Brasília, ABA. DOI: https://doi.org/10.1590/180943412017v14n2p081. Acesso em: 22 jun. 2021. 21p.

\section{Outros materiais}

ANVISA. 2019. "Peixe do rio Doce: riscos do consumo - Anvisa avaliou dados coletados sobre presença de metais em pescados na foz e na bacia do rio Doce. Concentrações de chumbo e mercúrio são as mais preocupantes". Site ANVISA, 17 jul. Disponível em: https://www.gov.br/anvisa/ptbr/assuntos/noticias-anvisa/2019/peixe-do-rio-doce-riscos-do-consumo

Acesso em: 22 jun. $2021 .^{21}$

ASCOM/ANVISA. 2019. Nota técnica número 8: Peixe do rio Doce, riscos do consumo. $14 p$.

COUZEMENCO, F. 2019. Indígenas de Areal cobram dívida de 40 anos da Petrobras. Século Diário. Disponível em: https://racismoambiental.net.br/2019/01/07/indigenas-de-areal-cobramdivida-de-40-anos-da-petrobras/ . Acesso em: 14 jun. $2021 .^{22}$

ESBRASIL. 2019. Atlântica Parque será inaugurado em fevereiro. ESBRASIL, 18 de jan. Disponível em: https://esbrasil.com.br/camburi-atlantica-parque/ . Acesso em: 22 jun. 2021.

GEPPEDES-UFES; CAT-UFES. 2015. Últimos dias em regência. Vitória, Regência Augusta, ES: GEPPEDES-UFES e CAT-UFES. Vídeo (8min04s) Disponível em: https://www.youtube.com/watch?v=cfFa_ybomiA\&t=5s. Acesso em: 09 jul. 2021.

IUCN. 2021-1. The IUCN Red List of threatened species. https://www.iucnredlist.org/ . Acesso em: 09 jun. 2021.

PAGATINI, Rafael (2017). Cavalinhos. Disponível em: https://rafaelpagatini.com/cavalinhos. Acesso em: 24 jun. 2021.

TAMAR - Projeto e Fundação Tamar. Espécies encontradas no Brasil. Disponível em: https://www.tamar.org.br/especies.php?cod=98. Acesso em: 14 jun. 2021.

XIMENES, Leonel. 2019. Vale cancela festa de inauguração de parque em Camburi. $A$ Gazeta, 28 de jan. Disponível em:

\footnotetext{
${ }^{21}$ Sobre esta referência, verificar observações na nota de rodapé número 6 .

22 Sobre a (in)disponibilidade da notícia em meio online, veja nota 10.
} 
https://www.agazeta.com.br/colunas/leonel-ximenes/vale-cancela-festa-deinauguracao-de-parque-em-camburi-0119. Acesso em: 22 jun. 2021. 